\title{
Prefacio. Museología en contextos tribales
}

\section{Bruno Brulon Soares}

Traductor: Scarlet Galindo Monteagudo

\section{(2) OpenEdition}

\section{Journals}

Edición electrónica

URL: https://journals.openedition.org/iss/2987

DOI: 10.4000/iss.2987

ISSN: 2306-4161

Editor

ICOM - International Council of Museums

Edición impresa

Fecha de publicación: 18 diciembre 2021

Paginación: 13-14

ISBN: 978-92-9012-446-7

ISSN: 2309-1290

\section{Referencia electrónica}

Bruno Brulon Soares, «Prefacio. Museología en contextos tribales», ICOFOM Study Series [En línea]

49-1 | 2021, Publicado el 18 diciembre 2021, consultado el 08 enero 2022. URL: http://

journals.openedition.org/iss/2987 ; DOI: https://doi.org/10.4000/iss.2987 


\section{Prefacio}

\section{Museología en contextos tribales}

Este nuevo número del ICOFOM Study Series reúne los artículos completos presentados en el Simposio Anual 2020 del ICOFOM, bajo el lema "Museología en contextos tribales", organizado en formato virtual por la Universidad de Sur de New Hampshire, en Estados Unidos. Este simposio fue concebido por el ICOFOM con el apoyo del Consejo Internacional de Museos de E.U.A., la Asociación de Museos Afroamericanos y la Universidad del Sur de New Hampshire con el objetivo de invitar a conferenciastas comprometidos con las prácticas indígenas para inspirar la concepción crítica de la teoría museológica de sus propias tribus, perspectivas y entendimientos indígenas del patrimonio cultural y de los museos.

A pesar de tener su sede en los Estados Unidos, este simposio en línea hizo posible reunir a miembros del ICOFOM de diferentes contextos del mundo e involucrar a los profesionales de los museos en un enfoque descolonial de la teoría de museos, registrando participantes de 48 países. Asumir que las perspectivas "tribales" sobre el museo pueden ayudar a abrir la museología a otras epistemologías e interpretaciones situadas del patrimonio cultural estuvo en el centro de los debates fomentados por este fructífero evento. La descolonización de la museología es un ejercicio activo y continuo que ha venido afrontando el ICOFOM con el proyecto de investigación "Museos, Acción Comunitaria y Descolonización", cuyos resultados han inspirado una serie de webinars y sin duda la concepción de este simposio anual organizado durante la pandemia de COVID-19. Este momento crítico para nuestras sociedades y para los museos a nivel mundial ha explicitado algunos problemas estructurales de nuestro tiempo y ha planteado algunas cuestiones fundamentales sobre la participación de diferentes grupos y minorías en el sector cultural.

Deseamos que los artículos seleccionados para este número puedan ayudar a arrojar luz sobre los desafíos de la museología en el presente que abordan algunos de los problemas clave que la teoría, tal como la conocemos, que no se pudieron abordar en el pasado. Así, los artículos plantean diversos temas, desde la repatriación hasta las relaciones de los museos con el mercado del arte y el derecho de los indígenas a hablar y hacerse autores de su propia representación en los museos. En este sentido, este número es la primera parte de un debate sobre "Descolonización de la museología" que se asumió como tema central de esta serie para 2021, y que se profundizará en nuestro próximo volumen, a finales de este año. 
Agradezco a todos los miembros de nuestro Comité Editorial y a los revisores pares que han trabajado arduamente en los últimos meses para que el ICOFOM Study Series pueda continuar como una publicación activa, incluso en tiempos difíciles. Este número fue el resultado del trabajo editorial directo de varios profesionales, entre los que se encuentran los editores invitados Yun Shun Susie Chung y Robert Denning de la Universidad del Sur de New Hampshire, nuestros socios a lo largo de este viaje, las secretarias editoriales Anna Leshchenko, Marion Bertin, Lynn Maranda, Elizabeth Weiser y Scarlet Galindo Monteagudo, y los correctores de pruebas, Katherine Sleight, MarieAlix Molinié-Andlauer y Sophia Tidwell, todos los cuales han hecho un trabajo sobresaliente. A todos los autores de los artículos aquí presentados, gracias por compartir sus enriquecedoras experiencias y por allanar el camino para nuevas perspectivas sobre museologías tribales y localizadas.

Bruno Brulon Soares

Río de Janeiro, Brasil.

Traducido por Scarlet Galindo Monteagudo 